\title{
PENGEMBANGAN PASAR TRADISIONAL DALAM MENINGKATKAN MINAT PENGUNJUNG DI PASAR TRADISIONAL BOYOLANGU KEC. BOYOLANGU TULUNGAGUNG
}

\author{
TRADITIONAL MARKET DEVELOPMENT IN INCREASING \\ VISITOR INTEREST IN BOYOLANGU TRADITIONAL MARKET \\ KEC. BOYOLANGU TULUNGAGUNG
}

\author{
Angkasawati, Devi Milasari \\ Program Studi Administrasi Publik, Fakultas Ilmu Sosial dan Ilmu Politik, \\ Universitas Tulungagung, Tulungagung, Indonesia \\ Program Studi Administrasi Publik, Fakultas Ilmu Sosial dan Ilmu Politik, \\ Universitas Tulungagung, Tulungagung, Indonesia \\ angkasawatiangkasawati@gmail.com
}

\begin{abstract}
ABSTRAKSI
Pasar Tradisional merupakan tempat bertemunya penjual dan pembeli dan ditandai dengan adanya transaksi penjual dan pembeli secara langsung dan biasanya ada proses tawar menawar. Dengan adanya pasar tradisioanal masyarakat akan sangat senang dimana pasar tersebut banyak menyediakan kebutuhan pokok dan kebutuhan sehari-hari dan tentunya harga juga lebih murah. Untuk itu pengembangan pasar tradisional perlu ditingkatkan. Agar minat pengunjung semakin meningkat diperlukan adanya perubahan atau inovasi agar lebih menarik minat pengunjung. Pengembangan pasar tradisioanal di Boyolangu dapat dilihat antara lain dengan : renovasi fisik, renovasi fisik, kegiatan kebersihan pasar dan lingkungan pasar, penataan tempat dan pengelompokan jenis dagangan, tertib administrasi, ketertiban dan keamanan. Sedangkan faktor yang mendukung antara lain para pedangan yang selalu mengikuti anjuran dari pengelola pasar, adanya petugas kebersihan, adanya dukungan yang baik dari Dinas Perindustrian dan Perdagangan. Adapun faktor yang menghambat dari pengembangan pasar tradisional dalam meningkatkan minat pengunjung antara lain : adanya
\end{abstract}




\section{Angkasawati,}

Pengembangan Pasar Tradisional Dalam Meningkatkan Minat Pengunjung Di Pasar Tradisional Boyolangu Kec. Boyolangu Tulungagung

masyarakat yang kurang sadar diri dengan membuang sampah di sekitar pasar, pengemasan

barang-barang dagangan yang kurang menarik, saluran air yang sering tersumbat. Pendekatan yang diinginkan adalah pendekatan kwalitatif yang dimaksud memperoleh gambaran yang mendalam tentang pengembangan pasar tradisional dalam meningkatkan minat pengunjung.

\section{Kata Kunci : Pengembangan Pasar Tradisional Meningkatkan Minat Pengunjung. ABSTRACTION}

Traditional markets are a place where sellers and buyers meet and are afraid of direct seller and buyer transactions and usually there is a bargaining process. With the traditional market, people will be very happy where the market provides a lot of basic needs and daily needs and of course the price is also cheaper. For this reason, the development of traditional markets needs to be increased. In order for increased visitor interest, changes or innovations are needed to attract more visitors. The development of traditional markets in Boyolangu can be seen, among others: physical renovation, physical renovation, activities of cleaning the market and the market environment, arranging the place and grouping the types of merchandise, administrative order, order and security. Meanwhile, the supporting factors include traders who always follow recommendations from market managers, the presence of cleaning officers, and good support from the Industry and Trade Office. The factors that hinder the development of traditional markets in increasing visitor interest include: the presence of people who are less aware of themselves by dumping trash around the market, packaging of merchandise that is less attractive, and airways that are often clogged. The desired approach is a qualitative approach that is intended to obtain an in-depth picture of traditional markets in order to increase visitor interest.

\section{Keywords: Traditional Market Development Increases Visitor Interest}


PUBLICIANA : JURNAL ILMU SOSIAL DAN ILMU POLITIK

VOLUME 14 NO 1

ISSN : 1979 - 0295 | E-ISSN : $2502-7336$

\section{PENDAHULUAN}

Sesuai berkembangnya dunia telah membawa perubahan pada pola hidup manusia terlebih pada kebutuhan masyarakat. Dengan bertambahnya jumlah penduduk akan berpengaruh pada jumlah sarana perekonomian bangsa. Terlebih dalam mencukupi kebutuhan rumah tangga/keluarga untuk terpenuhinya akan keperluan kebutuhan masyarakat pasar merupakan sarana/tempat sebagai slah satu fasilitas untuk bertemunya penjual dan pembeli. Bagi masyarakat pasar merupakan tempat/wadah untuk para bertemunya antara manusia dengan manusia lainnya.

Pasar tradisional mempunyai peran penting dalam memajukan pertumbuhan perekonomian di negara kita. Keberadaan pasar tradisional bagi masyarakat sangat masyarakat khususnya bagi masyarakat daerah/pinggiran dalam kegiatan berdagang, karena didalam pasar tradisionalharga juga lebih murah dan terjangkau bagi masyarakat dibanding belanja di mal/swalayan.

Menurut Sarifudin (1990) menyatakan bahwa pada perkembangan pasar menjadi pusat pertemuan antar masyarakat dari beberapa wilayah yang lebih luas, misalnya beberapa kecamatan. Pasar sebagai pusat ekonomi, melancarkan kegiatan yang bersifat ekonomi. Dalam hal bidang konsumsi pasar menyediakan kebutuhan primer dan sekunder. Sedangkan dalam bidang distribusi, apsar berperan besar terhadap penyebarluasan barang-barang kebutuhan masyarakat.

Pasar tradisional sebagai pasar yang pengelolaannya utamanya untuk melayani kebutuhan masyarakat. Pandangan orang pasar tradisional seperti pasar yang becek, kotor, bau dengan sampah-sampah, kadang-kadang berserakan bahkan sampai menggunung tumpukan-tumpukan sampahnya. Sehingga pasar tradisional menimbulkan kesan kumuh, bau, menjadikan pasar itu dijauhi dan masyarakat enggan ke pasar tersebut. Berbeda dengan 


\section{Angkasawati,}

Pengembangan Pasar Tradisional Dalam Meningkatkan Minat Pengunjung Di Pasar Tradisional

Boyolangu Kec. Boyolangu Tulungagung

kondisi pasar modern yang tentu lebih bersih, nyaman sehingga konsumen lebih memilih

berbelanja di swalayan.

Yang menonjol dari pasar tradisional atau pasar rakyat adalah para penjual tidak bersedia menjual barang dalam jumlah banyak karena terbatasnya modal yang mereka miliki dan mereka tidak mempunyai sarana yang lengkap untuk menyimpan barang dagangannya, seperti kulkas. Cadillah Emiliana dkk berpendapat bahwa yang menarik di pasar tradisional adalah para penjual dan pembeli dapat bertemu langsung dan saling terjadi tawar menawar antara penjual dan pembeli terhadap barang-barang yang dijual.

Berbeda dengan pasar modern yang lebih lengkap sarana/fasilitas dan tempat kelihatan lebih tertata bagus dan menarik bagi para konsumen sehingga akan membawa dampak bagi masyarakat dengan kehadiran pasar-pasar modern. Karena di pasar modern barang-barang yang diperlukan semua tersedia di pasar modern/swalayan/indomart dan lebih menarik tentunya. Para pedagang pasar tradisional kini mulai tersisih dan khawatir karena para pembeli berkurang. Letak pasar tradisional Boyolangu berdekatan dengan rumah penduduk, sehingga masyarakat akan lebih senang berbelanja. Inovasi dan pengembangan pasar tradisional perlu ada peningkatan agar fungsi dan peran 1 pasar tradisional lebih menarik dan banyak pengunjung yang berbelanja. Maka untuk mengantisipasi hal tersebut pasar tradisional Boyolangu perlu adanya pengembangan berupa inovasi-inovasi agar para masyarakat tetap memilih pasar tradisional Boyolangu sebagai tempat berbelanja kebutuhan primer maupun sekunder. Berdasarkan uraian diatas maka saya tertari mengambil judul

"PENGEMBANGAN PASAR TRADISIONAL DALAM MENINGKATKAN MINAT

\section{PENGUNJUNG"}

\section{A. RUMUSAN MASALAH}

1. Bagaimana pengembangan pasar tradisional dalam meningkatkan minat pengunjung di pasar tradisional Desa Boyolangu Kecamatan Boyolangu Tulungagung? 
PUBLICIANA : JURNAL ILMU SOSIAL DAN ILMU POLITIK

VOLUME 14 NO 1

ISSN : $1979-0295$ | E-ISSN : $2502-7336$

2. Apakah yang menjadi faktor pendorong dan penghambat dari pengembangan pasar tradisional dalam meningkatkan minat pengunjung di pasar tradisional Desa Boyolangu Kecamatan Boyolangu Tulungagung?

\section{B. KERANGKA TEORI}

\section{PENGERTIAN PENGEMBANGAN}

Menurut Nadler (Hardjana 2011) Pengembangan adalah kegiatan-kegiatan yang dilakukan dalam jangka waktu tertentu guna memperbesar kemungkinan untuk meningkatkan kinerjanya. Untuk itu pengembangan pasar merupakan sebuah usaha yang dilakukan dalam meningkatkan penjualan dari hasil produk yang dihasilkan. Jadi pengembangan merupakan proses adanya perubahan atau inovasi-inovasi baru dengan tujuan untuk meningkatkan adanya kwalitas yang terus membaik.

\section{PENGERTIAN PASAR TRADISIONAL}

Menurut Wicaksono dkk (2011) pasar tradisional merupakan tempat bertemunya para penjual dan pembeli yang ditandai dengan adanya tawar menawar secara langsung. Menurut pendapat Suyanto (2013:8) pasar tradisional adalah "pasar yang dibangun oleh pemerintah, swasta, koperasi atau swadaya masyarakat dengan tempat usaha berupa kios, toko, los dan tenda, dikelola oleh pedagang kecil, menengah, dan koperasi dengan usaha skala kecil dan modal kecil,dan dengan proses jual beli melalui tawar menawar."

Adapun manfaat pasar tradisional yang dapat kita dapatkan ketika berbelanja adalah :

1) Pasar tradisional buka lebih awal daripada tempat belanja lainnya aktifitasnyal cukup unik. Ketika masih banyak tempat belanja lain yang masih tutup atau belum buka, pasar tradisional dibuka lebih awal. Biasanya pedagang pasar tradisional telah membuka warung mereka dari fajar. Kegiatan ini memudahkan pembeli yang ingin mencari bahan masakan atau bahan untuk dikulak. Seperti penjual bahan makanan yang membeli barang dagangan ke pasar tradisional sebelum matahari terbit dan setelah itu ia akan menjual 


\section{Angkasawati,}

Pengembangan Pasar Tradisional Dalam Meningkatkan Minat Pengunjung Di Pasar Tradisional

Boyolangu Kec. Boyolangu Tulungagung

barang dagangannya. Selain itu, pemilik tempat makan yang membutuhkan bahan untuk memasak lebih memilih pasar tradisional sebagai tempat yang tepat untuk berbelanja.

2) Harga jauh lebih murah.

Tidak hanya menguntungkan dari segi waktu ketika kita membutuhkannya. Tetapi juga tentang harga pasar tradisional sendiri, menyediakan barang dagangan dengan harga murah dibandingkan dengan tempat belanja lainnya.

3) Bisa menawar

Harga murah oleh penjual tetapi masih bisa dikurangi untuk lebih murah atau ditawar.

4) Bisa lebih akrab dengan penjual

Proses tawar-menawar dan transaksi di pasar tradisional membuat kita akrab dan dikenal oleh penjual dan sebaliknya.

5) Berbelanja di pasar tradisional berarti meningkatkan ekonomi rakyat kecil dan mencintai produsen lokal. Pasar tradisional dipenuhi dengan pedagang kecil. Karena banyaknya sepermarket yang merajalela, terutama di kota-kota besar.

Dalam penelitian terdahulu Ummu Sholikah Tahun 2016 dalam pengembangan pasar tradisional ada 3 faktor yaitu 1) faktor fisik 2) faktor ekonomi dan (3) faktor sosial. Untuk itu inovasi-inovasi harus diwujudnyatakan agar minat pengunjung pasar tradisional semakin meningkat.

\section{METODE PENELITIAN}

\section{A. Type Penelitian}

Pendekatan kualitatif menjadi desai ndan metode penelitian bermaksud memperoleh gambaran yang mendalam tentang pengembangan pasar tradisional dalam meningkatkan minat pengunjung.

\section{B. Lokasi Penelitian}


PUBLICIANA : JURNAL ILMU SOSIAL DAN ILMU POLITIK

VOLUME 14 NO 1

ISSN : $1979-0295$ | E-ISSN : $2502-7336$

Lokasi di pasar tradisional Boyolangu Desa Boyolangu Kecamatan Boyolangu

Kabupaten Tulungagung.

\section{Teknik Pengumpulan Data}

Metode pengumpulan data yagn digunakan untuk memperoleh data :

1. Metode observasi

Yaitu teknik pengumpulan data yang digunakan untuk memperoleh data yang lebih akurat.

2. Metode wawancara

Merupakan teknik pengumpulan data dengan cara mengadakan tanya jawab secara langsung dengan imforman / narasumber.

3. Metode dokumentasi

Yaitu teknik pengumpulan data seperti berupa buku, dokumen yang berhubungan dengan obyek yang diteliti.

\section{Teknik Analisa Data}

Analisa data menurut Milles dan Huberman (dalam Sugiyono 2016:246) yang terdiri dari tiga komponen analisis yakni reduksi data, display data, menarik kesimpulan/verifiaksi. Analisis ini penulis anggap mampu menerjemahkan dengan mudah. Semua data yang ada menjadi sebuah informasi aktivitas dalam menganalisa dat a kualitatif yaitu antara lain :

a. Reduksi data

Data yang diperoleh dari lapangan karena banyak maka perlu dicatat secara teliti dan rinci. Dengan reduksi data yang dilakukan berulang-ulang merupakan salah satu cara penulis untuk mendapatkan falidasi data yang diperoleh. Sehingga dapat memberikan gambaran yang lebih jelas.

b. Penyajian data/data display 


\section{Angkasawati,}

Pengembangan Pasar Tradisional Dalam Meningkatkan Minat Pengunjung Di Pasar Tradisional Boyolangu Kec. Boyolangu Tulungagung

Data disusun dan disajikan dalam bentuk yang mudah dipahami, sehingga memberikan kemungkinan dalam penarikan kesimpulan.

c. Verifikasi/conclusion drawing

Data yang diperoleh kemudian dibuat penarikan kesimpulan. Dan kesimpulan tersebut diferifikasi secara terus menerus sehingga akan diperoleh kesimpulan yang bersifat grounded. Berikut gambar dari analisis data dari model interaktif menuruk Milles dan Huberman.

\section{Gambar 1}

Komponen-komponen Analisa dan Model Interaktif

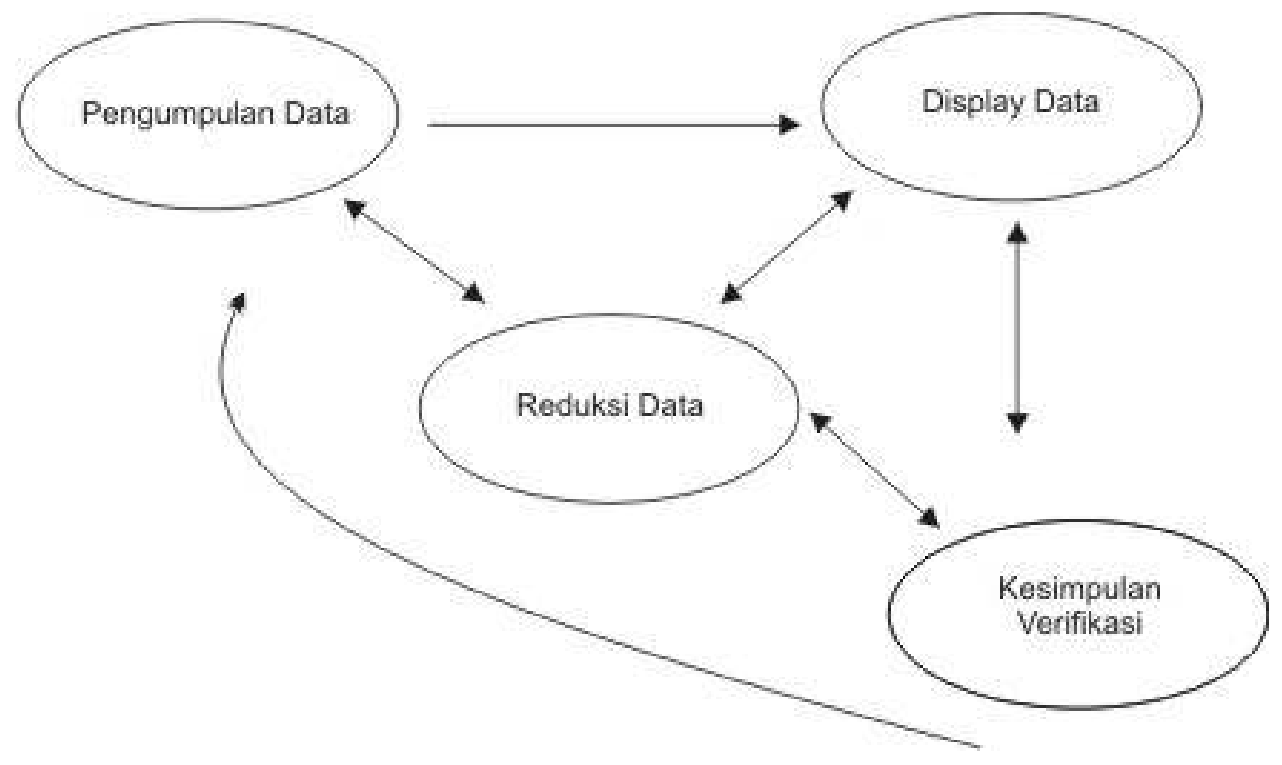


PUBLICIANA : JURNAL ILMU SOSIAL DAN ILMU POLITIK

VOLUME 14 NO 1

ISSN : $1979-0295$ |E-ISSN : $2502-7336$

\section{HASIL PEMBAHASAN}

1. Gambaran Umum UPT Dinas Perindustrian dan Perdagangan Kecamatan Boyolangu

Pasar tradisional Boyolangu tepatnya terletak dijalan raya Boyolangu Tulungagung. Secara topografi UPT Dinas Perindustrian dan Perdagangan Kecamatan Boyolangu terletak pada luas area pasar $\pm 5.500 \mathrm{~m}^{2}$ dengan jumlah pedagang \pm 300 orang dan terdiri dari 212 los bango dan 38 kios. Riwayat timbulnya pasar tradisional Boyolangu adalah dahulu yang semua lokasi pasar merupakan daerah yang berbentuk rawa atau berupa genangan air, maka potensi untuk dikelola sebagai lahan pertanianpun juga tidak memungkinkan, akhirnya rawa tersebut ditimbun dan digunakan sebagai lahan pasar.

2. Pengembangan pasar tradisional dalam meningkatkan minat pengunjung di Desa Boyolangu Kecamatan Boyolangu Tulungagung

Pengembangan pasar tradisional dalam meningkatkan minat pengunjung sangat diperlukan karena banyaknya pengaruh yang ditimbulkan dari banyaknya pasar modern, toko-toko milik perseorangan yang lebih menawarkan fasilitas yang lebih baik. Oleh karena itu pasar tradisional lebih meningkatkan minat pengunjung dengan melakukan inovasi-inovasi yang lebih menarik.

\section{a. Renovasi Fisik Pasar}

Dalam meningkatkan minat pengunjung pasar tradisional, renovasi fisik pasar sangat diperlukan. Pemeliharaan jalan pasar sangat diperlukan untuk memperlancar pedagang dan pengunjung pasar.

Dengan adanya renovasi keberadaan pasar tradisional diharapkan dapat meningkatkan minat pengunjung pasar tradisional. Sehingga pengunjung pasar 


\section{Angkasawati,}

Pengembangan Pasar Tradisional Dalam Meningkatkan Minat Pengunjung Di Pasar Tradisional

Boyolangu Kec. Boyolangu Tulungagung

tradisional akan merasa tertarik dan nyaman untuk berbelanja. Keberadaan pasar tradisional merupakan prioritas utama bagi pengunjung pasar tradisional di Boyolangu. Setelah melihat keberadaan pasar yang bersih, baik, nyaman, maka masyarakat akan mempunyai minat untuk berbelanja.

b. Melakukan kegiatan pembersihan jalan dalam pasar dan sekitar tempat pembuangan sampah

Untuk menghindari kesan kumuh, becek, kotor, bau dengan sampah yang menggunung diperlukan kesadaran untuk selalu menjaga kebersihan lingkungan pasar dan sekitar tempat pembuangan sampah. Maka untuk mendukung kegiatan tersebut pasar tradisional Boyolangu secara rutin harus melakukan kegiatan pembersihan jalan, baik didalam pasar dan disekitar tempat pembuangan sampah secara rutin.

Dengan lingkungan pasar yang bersih dan tidak bau, pedagang juga merasa nyaman dan tidak terganggu dengan bau tidak sedap dari sampah pasar. Jadi pedagang menjadi betah untuk berjualan di pasar tradisional Boyolangu . Dan dapat meningkatkan minat pengunjung pasar tradisional Boyolangu.

\section{c. Penataan tempat dan pengelompokan jenis dagangan}

Penataan tempat dan pengelompokan jenis dagangan merupakan strategi pengembangan pasar tradisional agar terlihat lebih menarik pengunjung.

Tempat para penjual/pedagang di pasar tradisional Boyolangu ada 5 pengelompokan yaitu :

1) Los bango sebelah utara untuk berjualan kain dan pakaian.

2) Los bango sebelah timur untuk berjualan sayur.

3) Los bango sebelah selatan untuk berjualan ikan dan ayam.

4) Los bango sebelah barat untuk berjualan gerabahdan barang pecah belah. 
PUBLICIANA : JURNAL ILMU SOSIAL DAN ILMU POLITIK

VOLUME 14 NO 1

ISSN : $1979-0295$ | E-ISSN : $2502-7336$

Dengan pengelompokan berdasarkan jenis barang yang dijual memudahkan pembeli untuk mencari barang yang perlukan.

\section{d. Tertib administrasi}

Dengan pemberian pelayanan yang tertib akan berdampak langsung dalam pengembangan pasar tradisional dalam meningkatkan minat pengunjung. UPT Dinas Perindustrian dan Perdagangan Kecamatan Boyolangu melakukan pelayanan kepada pedagang pasar Boyolangu. Pelayanan yang bisa dilakukan antara lain antara lain: permohonan Surat Ijin Usaha (SITU), pengaduan pedagang tentang tempat penjualan, dan pelayanan kepada masyarakat yang ingin berjualan di Pasar Tradisional Boyolangu.

Petugas UPT Dinas Perindustrian dan Perdagangan Kecamatan Boyolangu melakukan pelayanan yang baik terhadap pedagang dan masyarakat yang ingin berjualan di Pasar Tradisional Boyolangu.

Dengan bertambahnya pedagang yang berjualan di Pasar Tradisional Boyolangu akan berdampak terhadap peningkatan jumlah pengunjung Pasar Tradisional Boyolangu.

\section{e. Ketertiban dan Keamanan Pasar}

Rasa aman dan ketertiban para pengunjung di pasar tradisional sangat melindungi para pedagang dan pengunjung pasar. Dengan terciptanya ketertiban dapat membuat kedisiplinan para pedagang dan para pembeli.

\section{f. Menyediakan Toilet dan Tempat Cuci Tangan}

Untuk menjaga kebersihan dari virus-virus/kuman-kumn di pasar tradisional Boyolangu juga disediakan fasilitas berupa toilet dan tempat cuci tangan. Untuk tempat cuci tangan di pasar tradisional Boyolangu berada dipinggir jalan pintu masuk 


\section{Angkasawati,}

Pengembangan Pasar Tradisional Dalam Meningkatkan Minat Pengunjung Di Pasar Tradisional

Boyolangu Kec. Boyolangu Tulungagung

pasar tradisional. Pasar tradisional Boyolangu mempunyai tiga pintu masuk. Disetiap

pintu masuk disediakan tempat cuci tangan.

Dengan adanya fasilitas/tempat cuci tangan, diharapkan para pengunjung di pasar bisa terhindar dari virus-virus dan tetap menjaga prokes agar terhindar dari virus corona.

\section{g. Tempat parkir yang luas}

Fasilitas/tempat parkir juga tersedia di pasar tradisional Boyolangu. Dengan adanya tempat parkir yang luas diharapkan dapat meningkatkan minat pengunjung pasar tradisional Boyolangu.

\section{Faktor Pendukung dan Penghambat Dari Pengembangan Pasar Tradisional dalam}

\section{Meningkatkan Minat Pengunjung}

\section{Faktor Pendukung}

a. Para pedangan yang selalu mengikuti anjuran dari pengelola pasar tradisional Boyolangu.

Untuk meningkatkan minat pengunjung berbagai usaha pengembangan yang dilakukan pasar tradisional Boyolangu semua pedagang dalam melakukan kegiatan semua dapat bekerjasama dan mematuhi apa yang menjadi kebijakan dari pengelola pasar demi untuk meningkatkan minat pengunjung. Misalnya para pedagang pasar tradisional Boyolangu selalu menjaga kebersihan pasar dengan tidak membuang sampah di selokan, selalu disiplin melakukan registrasi surat ijin tempat usaha, selalu menjaga kebersihan fasilitas-fasilitas yang disediakan (toilet, parkir dan sebagainya).

b. Petugas kebersihan yang membersihkan jalan dalam pasar dan sekitar tempat pembuangan sampah secara rutin. 
PUBLICIANA : JURNAL ILMU SOSIAL DAN ILMU POLITIK

VOLUME 14 NO 1

ISSN : $1979-0295$ |E-ISSN : $2502-7336$

Kebersihan pasar tradisional menjadi pertimbangan utama bagi pengunjung pasar. Ketika suatu pasar tradisional terlihat bersih maka pengunjung akan merasa nyaman dan merasa puas. Oleh karena itu pengurus/pengelola pasar tradisional Boyolangu berusahas sangat mengutamakan kebersihan pasar supaya pasar tradisional Boyolangu terlihat bersih dan terhindar dari kesan kumuh.

Seperti yang diharapkan Kepala UPT Disperindag menugaskan kepada seluruh pembersih pasar tradisional Boyolangu agar membersihkan jalan daam pasar, los bango pedagang, sekitar tempat pembuangan sampah dan halaman pasar tradisional Boyolangu secara rutin. Agar air yang ada di dalam pasar tradisional tidak akan tersumbat dan pasar tidak akan kumuh dan becek apabila musin hujan tiba.

Untuk itulah petugas kebersihan pasar tradisional Boyolangu secara rutin dan bergiliran setiap hari membersihkan pasar. Petugas kebersihan pasar tradisional Boyolangu berjumlah 6 orang dan terbagi menjadi 2 shift agar pasar tradisional Boyolangu menjadi bersih.

\section{c. Petugas keamanan dan ketertiban Pasar Tradisional Boyolangu yang tertib dan disiplin}

Sebagian besar pedagang pasar tradisional Boyolangu ada yang meninggalkan barang dagangannya di dalam tempat jualannya. Agar tidak terjadi adanya pencurian paguyuban pedagang pasar mempunyai inisiatif untuk menugaskan seseorang untuk menjaga keamanan pasar tradisional Boyolangu. Orang yang menjaga ketertiban dan keamanan pasar tradisional tersebut berasal dari perwakilan pedagang pasar tradisional Boyolangu.

\section{d. Pengelola administrasi pasar yang melayani dengan baik}




\section{Angkasawati,}

Pengembangan Pasar Tradisional Dalam Meningkatkan Minat Pengunjung Di Pasar Tradisional Boyolangu Kec. Boyolangu Tulungagung

Administrasi yang baik akan mewujudkan suatu kepuasan bagi penerima dari administrasi tersebut. Penerima administrasi di UPT Dinas Perindustrian dan Perdagangan Kecamatan Boyolangu adalah pedagang pasar tradisional Boyolangu dan masyarakat. Bagi pedagang administrasi yang dibutuhkan adalah ijin tempat jualan, heregrestrasi surat ijin tempat jualan dan permasalahan yang terkait dengan tempat jualan.

Kepuasan dari pedagang dan masyarakat terhadap pelayanan dan pengelolaan administrasi di UPT Dinas Perindustrian dan Perdagangan Kecamatan Boyolangu mempunyai dampak terhadap terhadap keramaian pasar tradisional Boyolangu.

\section{e. Adanya dukungan dari pihak Pengelola Pasar}

Pengelola pasar tradisional Boyolangu selalu mendukung dan merespon apabila ada fasilitas di pasar tradisional Boyolangu yang mengalami kerusakan dengan cepat meresponnya terhadap kerusakan sarana dan prasarana yang ada di pasar tradisional Boyolangu. Hal tersebut sangat berdampak terhadap kenyamanan para pedagang dan pengunjung pasar tradisional Boyolangu.

\section{Faktor Penghambat}

\section{a. Masyarakat kurang sadar akan kebersihan}

Kurangnya kesadaran masyarakat, banyak yang membuang sampahdan sampah rumah tangga yang dibuang di pasar tradisional Boyolangu. Mereka membuang sampah hanya diletakkan bukan ditempatnya, sehingga membuat pasar berbau kurang sedap.

\section{b. Pengemasan barang dagangan yang kurang rapi dan kurang menarik}


PUBLICIANA : JURNAL ILMU SOSIAL DAN ILMU POLITIK

VOLUME 14 NO 1

ISSN : $1979-0295$ | E-ISSN : $2502-7336$

Barang dagangan dan pengemasannya tentunya menjadi prioritas utama bagi pembeli untuk membeli barang yang dibutuhkan. Barang dagangan yang kemasan manarik menjadi pertimbangan bagi para pembeli untuk memilih barang yang akan dibeli. Begitupun juga dengan pengemasan barang dagangan membuat barang dagangan menjadi mempunyai nilai lebih dan membuat daya tarik pembeli menjadi meningkat dengan tetap menjaga kualitas ekonomi.

Di pasar tradisional Boyolangu masih banyak ditemui barang dagangan yang masih diletakkan dipelatan los bango tanpa pengemasan. Hal inilah yang menjadi kualitas barang menjadi menurun. Barang dagangan dengan kualitas awalnya bagus karena diletakkan di pelataran membuat barang dagangan menjadi kurang bagus. Seperti sayur bayam yang kualitasnya bagus karena diletakkan dipelataran los bango, sayur bayam tersebut menjadi layu, tentunya dengna layunya sayur bayam tersebut menjadi kualitas dari sayur bayam tersebut menjadi menurun.

\section{c. Saluran air dalam pasar yang sering tersumbat}

Tersumbatnya saluran air di dalam pasar tradisional Boyolangu menyebabkan aliran air tidak dapat mengalir dengan lancar dan menyebabkan pasar tradisional Boyolangu menjadi banjir dan becek. Hal ini sering terjadi jika musim hujan tiba. 


\section{Angkasawati,}

Pengembangan Pasar Tradisional Dalam Meningkatkan Minat Pengunjung Di Pasar Tradisional

Boyolangu Kec. Boyolangu Tulungagung

\section{KESIMPULAN}

Pengembangan pasar tradisional dalam meningkatkan minat pengunjung di pasar tradisional Boyolangu Kecamatan Boyolangu Tulungagung terdapat beberapa tindakan untuk meningkatkan minat pengunjung yaitu :
a. Renovasi fisik pasar
b. Kegiatan pembersihan di jalan pasar
c. Penataan tempat dan pengelompokan jenis dagangan
d. Pelayanan administrasi yang baik
e. Ketertiban dan keamanan pasar
f. Tersedianya toilet dan cuci tangan
g. Tempat parkir yang luas

Adapun faktor-faktor pendukung dan penghambat pengembangan pasar tradisional dalam meningkatkan minat pengunjung yaitu :

\section{a. Faktor Pendukung}

1. Para pedagang yang selalu mengikuti anjuran dari pengelola pasar

2. Adanya petugas kebersihkan pasar

3. Adanya petugas keamanan pasar

4. Pengelola administrasi pasar yang baik pelayanannya

5. Dukungan pihak Dinas Perindustrian dan Perdagangan

\section{b. Faktor Penghambat}

1. Kurangnya tingkat kesadaran masyarakat dengan membuang sampah disembarang tempat.

2. Pengemasan barang dagangan yang kurang menarik.

3. Saluran air yang sering tersumbat 
PUBLICIANA : JURNAL ILMU SOSIAL DAN ILMU POLITIK

VOLUME 14 NO 1

ISSN : $1979-0295$ |E-ISSN : $2502-7336$

DAFTAR PUSTAKA

\section{A. BUKU}

Alwi, Hasan dkk. 2002. Kamus Besar Bahasa Indonesia Edisi Ketiga. Jakarta : Balai Pustaka.

Anthony, Chourmain, 2008. Pasar dan Masyarakat. Yogyakarata : Bentang Budaya

Bagus, Lorens. 2005. Kamus Filsafat. Jakarta : Gramedia Pustaka Utama.

Barkatullah. 2010. Hak-hak Konsumen. Bandung : Nusa Media

Daldjoeni. 2003. Geografi Kota dan Desa. Yogyakarta : Pustaka Pelajar.

Esther dan Didik. 2005. Membuat Pasar Tradisional Tetap Eksis. Jakarta : Sinar Harapan.

J. Moleong, Lexy, 2002. Metodologi Penelitian Kualitatif. Bandung : PT. Remaja Rosdakarya.

Mursid, M. 2010. Manajemen Pemasaran. Jakarta : Bumi Aksara.

Prastowo, Andi. 2011. Memahami Metode-metode Penelitian. Yogyakarta : Ar-Ruzz Media.

Subroto, DJ. 2007. Pengetahuan Sosial Ekonomi. Jakarta : Bumi Aksara.

Sumodiningrat, Gunawan. 1998. Membangun Perekonomian Rakyat. Yogyakarta : Pustaka Pelajar.

Supatmiyarsih, dkk, 2005. Statistik Terapan untuk Penelitian Ilmu-ilmu Sosial. Yogyakarta : Gajah Mada University Press.

Suyanto. 2013. Aplikasi Desain Grafis untuk Periklanan. Yogyakarta : Andi

Sugiyono 2016. Metodologi Penelitian 


\section{Angkasawati,}

Pengembangan Pasar Tradisional Dalam Meningkatkan Minat Pengunjung Di Pasar Tradisional Boyolangu Kec. Boyolangu Tulungagung

\section{B. PERATURAN PERUNDANG-UNDANGAN}

Keputusan Menteri Perindustrian dan Perdagangan RI No. 420/MPP/Kep/10/1997 Tentang Pedoman dan Pembinaan Pasar dan Pertokoan.

Peraturan Daerah Kabupaten Tulunagung Nomor 1 Tahun 2018 Tentang Penataan dan Pembinaan Pasar Rakyat, Pusat Perbelanjaan dan Toko Swalayan.

Peraturan Daerah Kabupaten Tulungagung Nomor 6 Tahun 2010 Tentang Perlindungan, Pemberdayaan Pasar Tradisional dan Penataan Serta Pengendalian Pasar Modern.

Peraturan Menteri Perdagangan Republik Indonesia Nomor 37/M-DAG/PER/5/2017 Tentang Pedoman Pembangunan dan Pengelolaan Sarana Perdagangan.

Undang-undang Dasar 1945 Pasal 33 Tentang Perekonomian Nasional.

Undang-undang Nomor 23 Tahun 2014 Tentang Pemerintah Daerah. 
PUBLICIANA : JURNAL ILMU SOSIAL DAN ILMU POLITIK

VOLUME 14 NO 1

ISSN : $1979-0295$ | E-ISSN : $2502-7336$

\section{Internet}

http://media.neliti.com (diakses pada Senin, 10 Februari 2020 pada pukul $16.00 \mathrm{WIB}$ ).

http://repository.iainpurwokerto.ac.id (diakses pada Rabu, 12 Februari 2020 pada pukul 18.00 WIB)

http://repository.usu.ac.id (diakses pada Jum'at, 14 Februari 2020 pada pukul 11.00 WIB)

http://www.pelajaran.co.id (diakses pada Minggu, 16 Februari 2020 pada pukul 20.00 WIB)

http://www.pasartradisional (diakses pada Senin, 13 Maret 2021 pada pukul 19.00 WIB) http://www.pengembanganpasar (diakses pada Kamis, 16 Maret 2021 pada pukul 13.00 WIB) 